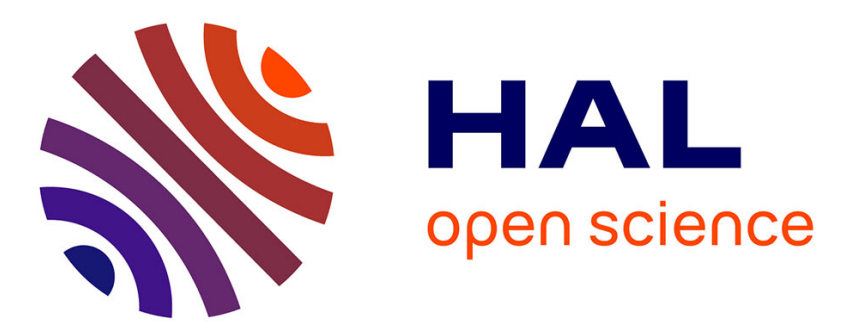

\title{
On the effect of temperature on the insertion of zinc into hydroxyapatite.
}

\author{
Sandrine Gomes, Jean-Marie Nedelec, Guillaume Renaudin
}

\section{To cite this version:}

Sandrine Gomes, Jean-Marie Nedelec, Guillaume Renaudin. On the effect of temperature on the insertion of zinc into hydroxyapatite.. Acta Biomaterialia, 2012, 8 (3), pp.1180-9. 10.1016/j.actbio.2011.12.003 . hal-00673057

\section{HAL Id: hal-00673057 https://hal.science/hal-00673057}

Submitted on 22 Feb 2012

HAL is a multi-disciplinary open access archive for the deposit and dissemination of scientific research documents, whether they are published or not. The documents may come from teaching and research institutions in France or abroad, or from public or private research centers.
L'archive ouverte pluridisciplinaire HAL, est destinée au dépôt et à la diffusion de documents scientifiques de niveau recherche, publiés ou non, émanant des établissements d'enseignement et de recherche français ou étrangers, des laboratoires publics ou privés. 
On the effect of temperature on the insertion of zinc into hydroxyapatite

Sandrine Gomes ${ }^{1,2}$, Jean-Marie Nedelec ${ }^{1,2^{*}}$ and Guillaume Renaudin ${ }^{1,2}$

${ }^{1}$ Clermont Université, ENSCCF, Laboratoire des Matériaux Inorganiques, BP 10448, 63000 Clermont-Ferrand, France.

${ }^{2}$ CNRS, UMR 6002, LMI, 63177 Aubière, France.

* corresponding author: j-marie.nedelec@univ-bpclermont.fr

Tel.: 00334734071 95, Fax.: 0033473405328 


\begin{abstract}
:
Rietveld analysis on X-ray powder diffraction patterns recorded from 28 hydroxyapatite samples containing various amount of zinc $(0,1.6,3.2$ and $6.1 \mathrm{wt} . \mathrm{Zn} \%)$ and heat treated at various temperatures (between $500^{\circ} \mathrm{C}$ and $1100^{\circ} \mathrm{C}$ ) have allowed to finely characterize the $\mathrm{Zn}$ insertion mechanism into the HAp crystal structure. The formation of $\mathrm{Zn}$-doped HAp was achieved above $900^{\circ} \mathrm{C}$ only. $\mathrm{Zn}$-doped $\mathrm{HAp}$ has the $\mathrm{Ca}_{10} \mathrm{Zn}_{x}\left(\mathrm{PO}_{4}\right)_{6}(\mathrm{OH})_{2-2 x} \mathrm{O}_{2 x}(0<x \leq 0.25)$ chemical composition with a constant $\mathrm{Ca} / \mathrm{P}$ ratio of 1.67 due to the insertion mechanism into the hexagonal channel (partial occupancy of the $2 b$ Wyckoff site with formation of linear OZn-O entities). Samples heat treated at $500{ }^{\circ} \mathrm{C}$ were almost single phase, HAp did not incorporate $\mathrm{Zn}$ and about half of the $\mathrm{Zn}$ atoms incorporated during the synthesis are not observable by X-ray powder diffraction (contained in an amorphous compound or physisorbed at the HAp surface). The reversible formation of $\mathrm{Zn}$-doped $\beta$-TCP phase was observed at $600^{\circ} \mathrm{C}$, reached its maximum content at $900^{\circ} \mathrm{C}$ and almost vanished at $1100^{\circ} \mathrm{C}$. The results presented here strengthen the recently described mechanism of $\mathrm{Zn}$ insertion in the interstitial $2 b$ Wyckoff position of the HAp structure, and explain the origin of the contradictory reports in the corresponding literature.
\end{abstract}




\section{1- Introduction}

Apatites $\mathrm{Ca}_{10}\left(\mathrm{PO}_{4}\right)_{6}(\mathrm{~F}, \mathrm{Cl}, \mathrm{OH})_{2}$, are a complex and diverse class of materials [1] which have gained increasing importance due to their biological role. One of the main constituents of bones and hard tissues in mammals is a calcium phosphate mineral whose structure closely resembles hydroxyapatite (HAp), $\mathrm{Ca}_{10}\left(\mathrm{PO}_{4}\right)_{6}(\mathrm{OH})_{2}$. The so-called biological apatite refers to poorly crystallized non-stoichiometric carbonate-containing HAp. The inorganic content varies from $65 \%$ in bones to $90 \%$ in dental enamel [2].

Because biological apatites are formed in biological conditions, they usually contain a large variety of doping elements that can also have some specific biological properties $(\mathrm{F}, \mathrm{Si}, \mathrm{Sr}$, $\mathrm{Mg}, \ldots)$. The important role of zinc has been put forward in the recent literature [3-6]. In effect, uptake and release of $\mathrm{Zn}$ in the body are strongly mediated by the bone reservoir, where the Zn content ranges from 125 to $250 \mathrm{ppm}$ (against 28-33 ppm for whole body) [6]. It has been demonstrated that zinc has a stimulatory effect on bone formation and mineralization in vivo and in vitro[7,8], and that $\mathrm{Zn}$ incorporation into implants promotes bone formation around the material [9-11], improves biological properties $[9,12]$ decreases the inflammatory response [13,14], and has an antibacterial effect [15].

In order to understand the mechanisms of incorporation of doping elements in HAp, and to correctly characterize natural and/or pathological nanocrystalline multi-substituted apatite materials, it is of great importance to perform detailed structural characterizations of substituted synthetic HAp. Our previous study has established the Zn location into the HAp structure [16]. For high synthesis temperatures $\left(1100^{\circ} \mathrm{C}\right), \mathrm{Zn}^{2+}$ cations are inserted along the hexagonal channel of HAp structure at the $2 b$ Wyckoff site forming O-Zn-O linear entities. $\mathrm{Zn}^{2+}$ leads to an insertion solid solution with general chemical formula $\mathrm{Ca}_{10} \mathrm{Zn}_{x}\left(\mathrm{PO}_{4}\right)_{6}(\mathrm{OH})_{2-}$ ${ }_{2 x} \mathrm{O}_{2 x}$, contrary to $\beta$-tricalcium phosphate $\left(\beta-\mathrm{TCP}, \beta-\mathrm{Ca}_{3}\left(\mathrm{PO}_{4}\right)_{2}\right)$ that realizes a substitution solid solution with chemical formula $\mathrm{Ca}_{3-x} \mathrm{Zn}_{x}\left(\mathrm{PO}_{4}\right)_{2}$. The present study aims to enlarge the 
investigation of the $\mathrm{Zn}^{2+}$ incorporation in HAp versus the temperature (heat treatment from $500{ }^{\circ} \mathrm{C}$ to $1100{ }^{\circ} \mathrm{C}$ ). This study was motivated by the contradictory reports in the literature on the $\mathrm{Zn}^{2+}$ incorporation in HAp; namely about its solubility, ranging from a few $\%$ to $15 \mathrm{~mol} \%$ [17-19], about the Zn atoms location, sorbed on the HAp surface (either six-fold or four-fold coordinated), or incorporated in one of the two crystallographic $\mathrm{Ca}$ sites (the nine-fold coordinated Ca1 and the seven-fold coordinated Ca2 sites) of HAp structure [17, 20-28].

\section{2- Materials and methods}

\subsection{Sol-gel elaboration}

The sol-gel route was used to synthesize undoped and Zn-doped HAp samples [16]. Briefly, to produce $2 \mathrm{~g}$ of pure $\mathrm{HAp}$ powder, $4.7 \mathrm{~g}$ of $\mathrm{Ca}\left(\mathrm{NO}_{3}\right)_{2} \cdot 4 \mathrm{H}_{2} \mathrm{O}$ (Aldrich) and $0.84 \mathrm{~g}$ of $\mathrm{P}_{2} \mathrm{O}_{5}$ (AvocadoResearch chemicals) were dissolved in anhydrous ethanol under stirring and refluxed at $85^{\circ} \mathrm{C}$ for $24 \mathrm{~h}$. Then, this solution was kept at $55^{\circ} \mathrm{C}$ for $24 \mathrm{~h}$, to obtain a consistent gel and further heated at $80^{\circ} \mathrm{C}$ for $10 \mathrm{~h}$ to form powder. Seven samples were prepared from this powder heat treated at $500^{\circ} \mathrm{C}, 600^{\circ} \mathrm{C}, 700^{\circ} \mathrm{C}, 800^{\circ} \mathrm{C}, 900^{\circ} \mathrm{C}, 1000^{\circ} \mathrm{C}$ and $1100^{\circ} \mathrm{C}$ during 15 h. To prepare $\mathrm{Zn}$-substituted samples, the required amounts of $\mathrm{Zn}\left(\mathrm{NO}_{3}\right)_{2} \cdot 6 \mathrm{H}_{2} \mathrm{O}$ (Acros Organics) was added to the solution, simultaneously with $\mathrm{Ca}\left(\mathrm{NO}_{3}\right)_{2} \cdot 4 \mathrm{H}_{2} \mathrm{O}$. Nominal compositions have been calculated assuming the previously described interstitial insertion mechanism for zinc into hydroxyapatite: composition $\mathrm{Ca}_{10} \mathrm{Zn}_{x}\left(\mathrm{PO}_{4}\right)_{6} \mathrm{O}_{2 x}(\mathrm{OH})_{2-2 x}$ with a constant $\mathrm{Ca} / \mathrm{P}$ ratio of 1.67 whatever the $\mathrm{Zn}$ content. Four series of samples have been synthesized with $x=0.00,0.25,0.50,1.00$ (corresponding to nominal $\mathrm{ZnO}$ weight percent of 0.0, 2.0, 3.9 and 7.6 wt. \% respectively). In the following, samples are labelled $\mathrm{Zn}_{x}-y$ with $x$ the amount of $\mathrm{Zn}^{2+}$-doping and $y$ the heat treatment temperature. A total of 28 samples were prepared and analysed. 


\subsection{X-Ray Powder Diffraction (XRPD)}

XRPD patterns were recorded on a X'Pert Pro PANalytical (Almelo, Netherlands) diffractometer, with $\theta-\theta$ geometry, equipped with a solid detector X-Celerator, and using CuK $\alpha$ radiation $(\lambda=1.54184 \AA$ ). XRPD patterns were recorded at room temperature in the interval $3^{\circ}<2 \theta<120^{\circ}$, with a step size of $\Delta 2 \theta=0.0167^{\circ}$ and a counting time of $200 \mathrm{~s}$ for each data value. A total counting time of about 200 min was used for each sample. Figure 1 shows XRPD patterns recorded for the $\mathrm{Zn}_{0.25}$-series. An XRPD pattern was collected from a pure $\mathrm{LaB}_{6}$ NIST standard (SRM 660b) by using the same experimental conditions in order to extract the instrumental resolution function to improve the peak profile fitting and to extract intrinsic microstructural parameters.

\subsection{Rietveld analyses}

Rietveld refinements of X-ray powder patterns were performed for each sample with the program FullProf.2k [29]. The procedure used (both data-collection and refinement strategy) corresponds to the general guidelines for structure refinement using the Rietveld (wholeprofile) method formulated by the International Union of Crystallography Commission on Powder Diffraction [30-32]. The initial structural parameters of hydroxyapatite, $\mathrm{Ca}_{10}\left(\mathrm{PO}_{4}\right)_{6}(\mathrm{OH})_{2}$, were taken from [33] : space group $P 6_{3} / m, Z=1, a=9.4218 \AA$ and $c=$ $6.8813 \AA$, 7 independent atomic positions: two Ca positions in sites $4 f(z=0.0007)$ and $6 h(x$ $=0.2465, y=0.9933)$, one $\mathrm{P}$ position in site $6 h(x=0.3968, y=0.3693)$, and four $\mathrm{O}$ positions in sites $6 h(x=0.331, y=0.480$ and $x=0.579, y=0.455), 12 i(x=0.3394, y=0.2569, z=$ $0.0694)$ and $4 e$ ( $z=0.192$ with a half occupancy). Zn atoms were placed in the $2 b$ Wyckoff site at $(0,0,0)[16]$, after systematic verification of their absence in the $\mathrm{Ca} 1$ and $\mathrm{Ca} 2$ calcium sites. The initial structural parameters of $\beta$-TCP, $\mathrm{Ca}_{3}\left(\mathrm{PO}_{4}\right)_{2}$, were taken from [34] : space 
group $R 3 c, \mathrm{Z}=21, a=10.4352 \AA$ and $c=37.4029 \AA$, 18 independent atomic positions: five Ca positions (three in site $18 b$ and two in site $6 a$ at one-half occupancy), three $\mathrm{P}$ positions (two in site $18 b$ and one in site $6 a$ ), and ten O positions (nine in site $18 b$ and one in site $6 a$ ). Zincite ( $\mathrm{ZnO}$ with structural parameters taken from [35]), lime ( $\mathrm{CaO}$ with structural parameters taken from [36]), and $\alpha-\mathrm{TCP}\left(\mathrm{Ca}_{3}\left(\mathrm{PO}_{4}\right)_{2}\right.$ with structural parameters taken from [37]) were observed as minor and temperature dependant phases. The following parameters were first refined: scale factors, zero shift, line profile parameters, lattice parameters, preferential orientations and asymmetry parameters. In a second step atomic displacement factors were refined (only three thermal displacement values were considered - one for divalent cations, one for $\mathrm{P}$ and one for $\mathrm{O}$ - in order to avoid strong correlation between site occupancies and atomic displacement factors [30-32]), as well as atomic coordinates from the HAp structure. Anisotropic average apparent crystal size parameters were refined in a third step for the HAp phase (refinements were performed with spherical harmonics by using the corresponding 6/m Laue class of symmetry). Site occupancies of cations, phosphate and hydroxyl anions were systematically checked in the last runs. Scholzite, $\mathrm{Zn}_{2} \mathrm{Ca}\left(\mathrm{PO}_{4}\right)_{2}\left(\mathrm{H}_{2} \mathrm{O}\right)_{2}$, and dehydrated scholzite, $\mathrm{CaZn} \mathrm{P}_{2}\left(\mathrm{PO}_{4}\right)_{2}$ were never observed in any of the 28 samples.

\subsection{Micro-Raman spectroscopy}

Micro-Raman spectra were recorded at room temperature using a Jobin-Yvon T64000 device. The spectral resolution obtained with an excitation source at $514.5 \mathrm{~nm}$ (argon ion laser line, Spectra Physics 2017) is about $1 \mathrm{~cm}^{-1}$. The Raman detector was a charge coupled device (CCD) multichannel detector cooled by liquid nitrogen to $140 \mathrm{~K}$. The laser beam was focused onto the sample through an Olympus confocal microscope with 100x magnifications. Measured power at the sample level was kept low (less than $10 \mathrm{~mW}$ ) in order to avoid any damage of the material. The Raman scattered light was collected with the microscope 
objective at $180^{\circ}$ from the excitation and filtered with an holographic Notch filter before being dispersed by a single grating (1800 grooves per $\mathrm{mm}$ ). Spectra were recorded in the frequencies ranges $100 \mathrm{~cm}^{-1}-1500 \mathrm{~cm}^{-1}$ and $3000 \mathrm{~cm}^{-1}-3800 \mathrm{~cm}^{-1}$ in order to investigate respectively the vibration modes of phosphate and hydroxyl stretching. Spectra were analysed by a profile fitting procedure using a Lorentzian function.

\section{3- Results}

Elemental analysis of the samples by ICP-AES confirms the global nominal compositions as usually observed with this synthesis procedure [38] (Table 1).

\subsection{Mineralogical composition}

Quantitative phase analyses were extracted from Rietveld refinements. Refined mineralogical compositions of the samples are gathered in Table 2. Figure 2 shows the thermal evolution of the HAp, $\beta$-TCP, $\mathrm{ZnO}$ and $\mathrm{CaO}$ weight percents (wt. \%). HAp was constantly the major phase. The HAp minimal content is about 65 wt. \% observed in $\mathrm{Zn}_{1.00}-900$. The four series present a similar thermal behaviour: large majority of HAp phase for the sample heat treated at $500^{\circ} \mathrm{C}$ (99 wt. $\%$ for $\mathrm{Zn}_{0.00^{-}} 500,98$ wt. \% for $\mathrm{Zn}_{0.25}-500$, 97 wt. $\%$ for $\mathrm{Zn}_{0.50^{-}} 500$ and 95 wt. $\%$ for $\mathrm{Zn}_{1.00}-500$; i.e. slightly decreasing when increasing the $\mathrm{Zn}$ doping level from $\mathrm{Zn}_{0.00}-500$ to $\left.\mathrm{Zn}_{1.00}-500\right)$. The weight percent of HAp decreases when temperature increases from $500^{\circ} \mathrm{C}$ to $900^{\circ} \mathrm{C}$ (keeping the decreasing sequence from the $\mathrm{Zn}_{0.00}$-series to the $\mathrm{Zn}_{1.00}$-series: $80 \mathrm{wt}$. $\%$ for $\mathrm{Zn}_{0.00^{-}}-900,77$ wt. $\%$ for $\mathrm{Zn}_{0.25}-900,70$ wt. $\%$ for $\mathrm{Zn}_{0.50^{-}}-900$ and 65 wt. $\%$ for $\mathrm{Zn}_{1.00^{-}}$ 900), then it increases from $900^{\circ} \mathrm{C}$ to $1100^{\circ} \mathrm{C}$ to reach almost single phase samples and keeping still the decreasing sequence from the $\mathrm{Zn}_{0.00}$-series to the $\mathrm{Zn}_{1.00}$-series $(98$ wt. $\%$ for $\mathrm{Zn}_{0.00}-1100,97$ wt. \% for $\mathrm{Zn}_{0.25}-1100,95$ wt. \% for $\mathrm{Zn}_{0.50}-1100$ and 94 wt. \% for $\left.\mathrm{Zn}_{1.00}-1100\right)$. 
In a first step $\mathrm{ZnO}$ and $\mathrm{CaO}$ wt. \% show opposite evolution (Figures $2 \mathrm{~b}$ and $2 \mathrm{c}$ ). Between $500^{\circ} \mathrm{C}$ and $800^{\circ} \mathrm{C}$, during the formation of $\beta$-TCP, the $\mathrm{ZnO}$ content decreases whereas the $\mathrm{CaO}$ content increases. In a second step both $\mathrm{ZnO}$ and $\mathrm{CaO}$ wt. \% decrease. One can note the formation of few weight percents of metastable $\alpha$-TCP at $600^{\circ} \mathrm{C}$ for all series $(5$ wt. $\%$ for $\mathrm{Zn}_{0.00}-600,4$ wt. $\%$ for $\mathrm{Zn}_{0.25}-600$ and $\mathrm{Zn}_{0.50}-600$, and 3 wt. $\%$ for $\mathrm{Zn}_{1.00^{-}}-600$ ) that quickly disappears at $900^{\circ} \mathrm{C}$ for the $\mathrm{Zn}_{0.00}$-series and already at $700^{\circ} \mathrm{C}$ for the three $\mathrm{Zn}$-doped series.

\subsection{Zn insertion into the HAp structure}

Thermal evolution of the HAp lattice parameters evidences the late $\mathrm{Zn}$ incorporation into the HAp structure (Figure 3, Table 3). Evolutions of the Zn-doped series start to slightly diverge from the undoped series at $900^{\circ} \mathrm{C}$, and are really different at $1000^{\circ} \mathrm{C}$ and $1100^{\circ} \mathrm{C}$. In a first step, from $500^{\circ} \mathrm{C}$ to $800^{\circ} \mathrm{C}$, all the series (undoped and $\mathrm{Zn}$-doped) show a decrease, of about $0.15 \%$, of the unit cell volume (Figure 3c) connected with the increase of crystallinity. Between $800^{\circ} \mathrm{C}$ and $900^{\circ} \mathrm{C}$ the undoped series shows a slight increase, of about $0.02 \%$, that

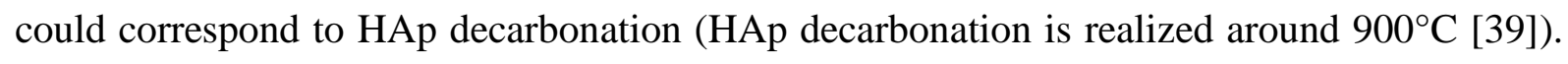
From $900^{\circ} \mathrm{C}$, the $\mathrm{Zn}$-doped series differ from undoped series: unit cell volumes of $\mathrm{Zn}$-doped HAp are larger than undoped HAp. More interesting is the lattice parameters evolution: $a$ lattice parameter of Zn-doped HAp is smaller (Figure 3a) whereas $c$ lattice parameter of $\mathrm{Zn}$ doped HAp is larger (Figure 3b) than for undoped HAp. This correlates with previous observation ${ }^{16}$ and is attributed to the interstitial mechanism of $\mathrm{Zn}^{2+}$ insertion into HAp (in the $2 b$ Wyckoff site). Insertion of small $\mathrm{Zn}^{2+}$ cation, contrary to $\mathrm{Mg}^{2+}$ case with relatively similar ionic radii [40], induces an increase of the unit cell volume because it inserts the hexagonal channel (creating linear O-Zn-O units oriented along the $c$ hexagonal axis) and it not simply substitutes larger $\mathrm{Ca}^{2+}$ cations. We have here a clear indication that cationic size is not the only parameter to consider in order to explain the substitution mechanism into the HAp 
structure. Certainly the ability to form linear O-M-O 'complex' with short $M-\mathrm{O}$ distances, around $1.7 \AA$ [16], should be considered $\left(\mathrm{Zn}^{2+}\right.$ allows the formation of O-Zn-O entities, whereas slightly smaller $\mathrm{Mg}^{2+}$ not).

Refinement of Zn occupancy in the $2 b$ Wyckoff site directly confirms the high temperature insertion of $\mathrm{Zn}$ into HAp structure (Figure 3d, Table 3). Up to $900^{\circ} \mathrm{C}$ few $\mathrm{Zn}$ insertion is observed: occupancy around $3.5 \%$ for the $2 b$ Wyckoff site corresponding to the refined $\mathrm{Ca}_{10} \mathrm{Zn}_{0.07}\left(\mathrm{PO}_{4}\right)_{6}(\mathrm{OH})_{1.86} \mathrm{O}_{0.14}$ composition. At $1000^{\circ} \mathrm{C}$, the $\mathrm{Zn}$ occupancy is about $9 \%$, corresponding to the refined $\mathrm{Ca}_{10} \mathrm{Zn}_{0.18}\left(\mathrm{PO}_{4}\right)_{6}(\mathrm{OH})_{1.64} \mathrm{O}_{0.36}$ composition. And the $\mathrm{Zn}$ occupancy reaches about $11 \%$ at $1100^{\circ} \mathrm{C}$, corresponding to the refined $\mathrm{Ca}_{10} \mathrm{Zn}_{0.22}\left(\mathrm{PO}_{4}\right)_{6}(\mathrm{OH})_{1.56} \mathrm{O}_{0.44}$ composition. The three $\mathrm{Zn}$-doped series show extremely similar behaviours indicating that maximal $\mathrm{Zn}$ insertion into HAp structure is already reached for the $\mathrm{Zn}_{0.25}$-series, in agreement with previous result [16] and with mineralogical compositions (excess of zincite in both $\mathrm{Zn}_{0.50^{-}}$and $\mathrm{Zn}_{1.00^{-}}$-series).

\subsection{Zn substitution in $\beta$-TCP}

Thermal evolution of $\beta$-TCP lattice parameters and unit cell volumes indicates that $\mathrm{Zn}$ substitutes calcium during the $\beta$-TCP formation; i.e. already at $600^{\circ} \mathrm{C}$ (Figure 4 , Table 4 ). Unit cell volumes of $\beta$-TCP from $\mathrm{Zn}$-doped series are smaller (Figure 4c) than those from the undoped series whatever the heat treatment. The maximum difference between the $\mathrm{Zn}$-doped series and the undoped series is observed between $600^{\circ} \mathrm{C}$ and $800^{\circ} \mathrm{C}$, and then is decreasing. Both $a$ and $c$ lattice parameters show similar behaviour (Figures $4 \mathrm{a}$ and $4 \mathrm{~b}$ ), in agreement with a substitution mechanism of $\mathrm{Ca}^{2+}$ by smaller $\mathrm{Zn}^{2+}$ and in agreement with previous indication [16]. When $\beta$-TCP is destabilized to the benefit of HAp (i.e. above $900^{\circ} \mathrm{C}$ ), $\mathrm{Zn}$ is extracted from the $\beta$-TCP structure to insert the HAp one (shown by the decrease of the difference between the $\mathrm{Zn}$-doped and the undoped series at $1000^{\circ} \mathrm{C}$ and $1100^{\circ} \mathrm{C}$ ). 
The calcium sites substituted by zinc are temperature dependant (Figure 4d). The two Ca4 and $\mathrm{Ca} 5$ sites are subject to $\mathrm{Zn}$ substitution; i.e. calcium sites from the low density column described by Yashima et al. [34]. In a first step (at $600^{\circ} \mathrm{C}$ ) $\mathrm{Zn}$ fully substitutes calcium in the $\mathrm{Ca} 4$ site and is almost not present in the Ca5 site. This trend is totally reversed at $800^{\circ} \mathrm{C}$, and returns at $1000^{\circ} \mathrm{C}$. The $\mathrm{Zn}$ substitution in the $\mathrm{Ca} 4$ site lead to a composition of about $\mathrm{Ca}_{2.83} \mathrm{Zn}_{0.17}\left(\mathrm{PO}_{4}\right)_{2}$ (samples heat treated at $600^{\circ} \mathrm{C}$ and $1000^{\circ} \mathrm{C}$ ), whereas $\mathrm{Zn}$ substitution in the Ca5 site lead to a composition of about $\mathrm{Ca}_{2.67} \mathrm{Zn}_{0.33}\left(\mathrm{PO}_{4}\right)_{2}$ (samples heat treated at $800^{\circ} \mathrm{C}$ ). The difference in term on $\mathrm{Zn}$ incorporation level in $\beta$-TCP is not strongly marked in the three Zn-doped series, though refined $\mathrm{Zn}$ substitution level is globally increasing when passing from the $\mathrm{Zn}_{0.25}$-series to the $\mathrm{Zn}_{1.00}$-series. Despite the homogeneous behaviour on the $\mathrm{Zn}$ substitution for the three Zn-doped series (Table 3, Figure 4d), one should take care about the significance of the refined $\mathrm{Zn}$ occupancy parameters when $\beta$-TCP is present as minor phase: for samples heat treated at $600^{\circ} \mathrm{C}$ and $1000^{\circ} \mathrm{C}$ with less than $10 \mathrm{wt} \%$ of $\beta$-TCP (i.e. when $\mathrm{Zn}^{2+}$ cations are observed to substitute exclusively the Ca4 site). Such carefulness is not justified for $\mathrm{Zn}$ substitution in the $\mathrm{Ca} 5$ site as it concerns samples containing higher quantities of $\beta$-TCP (up to $25 \mathrm{wt} \%$ for samples heat treated at 800 and $900{ }^{\circ} \mathrm{C}$, Table 3).

\subsection{Microstructural effect of $\mathrm{Zn}$}

Microstructural parameters have been extracted from Rietveld refinements with anisotropic crystal size for HAp. Crystal sizes for HAp along the $[h h 0]$ and the $[00 l]$ directions are indicated in Table 3, and isotropic crystal sizes for $\beta$-TCP are indicated in Table 4. Both HAp and $\beta$-TCP show relatively equivalent average crystal sizes and similar temperature evolutions (increasing from about $200-300 \AA$ at $500^{\circ} \mathrm{C}$ to about $800 \AA$ at $1100^{\circ} \mathrm{C}$ ). Nevertheless $\beta$-TCP shows somewhat smaller crystal size for moderate temperature (up to $\left.800^{\circ} \mathrm{C}\right)$. The HAp crystal size anisotropy, calculated by considering the $[00 l] /[h h 0]$ direction 
sizes ratio, is represented in Figure 5. It continuously decreases when increasing the temperature to reach tabular HAp crystals at $1100^{\circ} \mathrm{C}$ (isotropic morphology with a ratio close to unity). Undoped HAp crystals and Zn-doped HAp crystals showed extremely similar behaviour in term of size and anisotropy.

\subsection{Micro-Raman spectroscopy}

Raman spectra in the range $150-1500 \mathrm{~cm}^{-1}$ show the four modes of vibration of phosphate tetrahedron. Figure 6 presents the thermal evolution of the $v_{1}$ symmetric stretching mode (the most intense signal) of $\left[\mathrm{PO}_{4}\right]$ for the undoped $\mathrm{Zn}_{0.00^{-}}$and the $\mathrm{Zn}$-doped $\mathrm{Zn}_{0.25}$-series. Results from spectral deconvolution are gathered in Table 5 (Raman shift and Full Width at Half Maximum, FWHM). The Raman shift of the $v_{1}$ mode is not temperature dependant for the undoped series, always observed at $963 \mathrm{~cm}^{-1}$. The FWHM is continuously decreasing (from 6.4 to $3.7 \mathrm{~cm}^{-1}$ ) when increasing the temperature of the heat treatment, indicating the increase of crystallinity. The $\mathrm{Zn}$-doped $\mathrm{Zn}_{0.25}$-series shows a similar behaviour in a first step (from $500^{\circ} \mathrm{C}$ to $800^{\circ} \mathrm{C}$ ) with the increase of crystallinity. Then from $900^{\circ} \mathrm{C}$ to $1100^{\circ} \mathrm{C}$ the insertion of $\mathrm{Zn}^{2+}$ cations into HAp structure was evidenced by the appearance of two new $v_{1}$ components at $959 \mathrm{~cm}^{-1}$ and $970 \mathrm{~cm}^{-1}[16]$. The simultaneous increase of the FWHM indicates a loss of order (due to statistic disorder in the hexagonal channel) when $\mathrm{Zn}^{2+}$ inserts the HAp crystal structure.

Observations of the $[\mathrm{OH}]$ stretching modes (Figure 7) corroborate those from $v_{1}\left[\mathrm{PO}_{4}\right]$. Increase of the crystallinity from $500^{\circ} \mathrm{C}$ to $1100^{\circ} \mathrm{C}$ for the undoped $\mathrm{Zn}_{0.00}$-series is evidenced by the decrease of FHWM of the band centred at $3572 \mathrm{~cm}^{-1}$ (from $10 \mathrm{~cm}^{-1}$ to $3 \mathrm{~cm}^{-1}$; Table 5). A similar behaviour is observed for the $\mathrm{Zn}_{0.25}$-series up to $800^{\circ} \mathrm{C}$, and then the appearance of a new band at $3410 \mathrm{~cm}^{-1}$ is attributed to the $\mathrm{Zn}^{2+}$ insertion in the $2 b$ site. This new band increases in intensity from $900^{\circ} \mathrm{C}$ to $1100^{\circ} \mathrm{C}$, simultaneously with the increase of the FWHM 
of the band at $3572 \mathrm{~cm}^{-1}$. This highlights that the HAp crystallinity deterioration (statistic disorder in the hexagonal channel due to partial occupancy of the $2 b$ site) is directly correlated to the $\mathrm{Zn}$ insertion. Spectra from the $\mathrm{Z}_{0.25}-1100$ sample show the presence of a third $[\mathrm{OH}]$ stretching mode at $3584 \mathrm{~cm}^{-1}$ (shoulder on the main $3572 \mathrm{~cm}^{-1}$ component), certainly also correlated to the $\mathrm{Zn}$ insertion.

\section{4- Discussion}

During heat treatment, a partial and reversible transformation of HAp into $\beta$-TCP is observed (Figure 2a). $\beta$-TCP is completely absent in samples heat treated at $500^{\circ} \mathrm{C}$, and is almost absent in samples heat treated at $1100^{\circ} \mathrm{C}$ (between 1.5 and $3.5 \mathrm{wt}$ \%). The almost single phase feature of samples heat treated at $1100^{\circ} \mathrm{C}$ definitively strengthens the insertion mechanism for $\mathrm{Zn}$ (by validating the used constant $\mathrm{Ca} / \mathrm{P}$ ratio of 1.67 whatever the $\mathrm{Zn}$ content). The $\beta$-TCP phase reaches its maximal concentration at $900^{\circ} \mathrm{C}$ (19 wt. $\%$ for $\mathrm{Zn}_{0.00^{-}}$ 900, 21 wt. \% for $\mathrm{Zn}_{0.25}-900,26$ wt. \% for $\mathrm{Zn}_{0.50}-900$ and 28 wt. \% for $\left.\mathrm{Zn}_{1.00}-900\right)$. Thermal evolution of HAp lattice parameters (Figure 3) clearly highlights that $\mathrm{Zn}$ inserted the HAp structure from $1000^{\circ} \mathrm{C}$ only, whereas it substitutes the $\beta$-TCP structure already at $600^{\circ} \mathrm{C}$ (the temperature of the $\beta$-TCP formation; Figure 4). Only weak $\mathrm{Zn}$ incorporation in HAp is realized before $1000^{\circ} \mathrm{C}$. Such a high temperature for $\mathrm{Zn}$ insertion in HAp can explain the divergences founded in the literature concerning the mechanism of $\mathrm{Zn}$ incorporation $[16,17,20-23]$. The similar thermal evolution of lattice parameters of the undoped and the $\mathrm{Zn}$ doped series before $900^{\circ} \mathrm{C}$ indicates that almost no $\mathrm{Zn}$ incorporates the $\mathrm{HAp}$ structure up to $800^{\circ} \mathrm{C}$. Only $\mathrm{Zn}$ physisorbed at the HAp surface could be envisaged (as proposed by Bazin et al. [25] and Bigi et al. [19]). Raman spectra fully agree with the late $\mathrm{Zn}$ insertion into the HAp structure: both $\left[\mathrm{PO}_{4}\right]$ and $[\mathrm{OH}]$ stretching modes indicate a structural modification from $900^{\circ} \mathrm{C}$ only (Figures 5 and 6). This new understanding of the high temperature mechanism of 
$\mathrm{Zn}^{2+}$ incorporation in HAp lattice explains previously published results on related materials such as the crystallinity dependence of the maximum zinc content in HAp or the crystallinity dependence of the bone formation promotion [6]. It also clearly demonstrates that precipitation of a $\mathrm{Zn}$-containing apatite layer, as observed by wang et al. [9], is not a layer constituted of a Zn-doped HAp compound.

The $\beta$-TCP content increase from $\mathrm{Zn}_{0.00}$-series to $\mathrm{Zn}_{1.00}$-series, observed whatever the temperature, results in the late $\mathrm{Zn}$ incorporation into HAp. The fact that $\mathrm{Zn}$-insertion in HAp is not realized for the moderate temperatures is at the origin of the $\beta$-TCP-stabilizing feature of zinc described in the literature [19,22,41]. Zn-doped $\beta$-TCP crystals were somewhat smaller than those from undoped series (Table 4), and Zn-doped HAp crystal anisotropy of morphology was somewhat smaller than the one for undoped series (Figure 5). Such weak differences between the undoped and the $\mathrm{Zn}$-doped series are contradictory with previously reported inhibiting effect of zinc on HAp crystallisation and the preference of $\mathrm{Zn}$ for $\beta$-TCP $[17,41,42]$. Present results clearly evidence that the Zn-stabilizing feature is temperaturedependant ( $\mathrm{Zn}$ stabilizes $\beta$-TCP below $900^{\circ} \mathrm{C}$ and stabilizes HAp above $900^{\circ} \mathrm{C}$ ). The $\mathrm{Zn}$ incorporation into $\beta$-TCP with a $\mathrm{Ca} / \mathrm{P}$ ratio of 1.5 induces the formation of $\mathrm{CaO}$ around $900^{\circ} \mathrm{C}$ (Figure 2c). The following $\mathrm{Zn}$ incorporation into $\mathrm{HAp}$ (from $900^{\circ} \mathrm{C}$ ) with a $\mathrm{Ca} / \mathrm{P}$ ratio of 1.67 , the nominal one, explains the complete disappearance of $\mathrm{CaO}$ in the four samples heat treated at $1100^{\circ} \mathrm{C}$ (Table 2, Figure 2c).

Samples heat treated at $500^{\circ} \mathrm{C}$, in which HAp (that do not yet incorporate $\mathrm{Zn}$, or weakly) is the only calcium phosphate phase, contain about half of the zincite, $\mathrm{ZnO}$, nominal content only (1.2 wt. \% against the nominal 2.0 wt. \% for the $\mathrm{Zn}_{0.25}$-series, 2.2 wt. \% against the nominal 3.9 wt. $\%$ for the $\mathrm{Zn}_{0.50}$-series, and 4.5 wt. $\%$ against the nominal 7.6 wt. $\%$ for the $\mathrm{Zn}_{1.00}$-series). This indicates that about half of the incorporated $\mathrm{Zn}$ atoms were not detectable by XRPD. They are either in an amorphous compound and/or physisorbed at the surface of 
HAp. This situation persists up to $800^{\circ} \mathrm{C}$ in a more pronounced manner due to $\mathrm{Zn}$ incorporation into $\beta$-TCP, next the weight percent of $\mathrm{ZnO}$ phase increases to reach a maximum at $900-1000^{\circ} \mathrm{C}$ (when $\beta$-TCP is destabilized to the profit of HAp that does not yet fully incorporate $\mathrm{Zn}$ ). The $\mathrm{ZnO}$ content observed in samples heat treated at $1100^{\circ} \mathrm{C}$ (almost absent in $\mathrm{Zn}_{0.25}-1100,1.1$ wt. \% in $\mathrm{Zn}_{0.50^{-}}-1100$, and 4.8 wt. \% in $\mathrm{Zn}_{1.00^{-1}} 100$ ) traduces the fact that HAp is not allowed to incorporate all the nominal $\mathrm{Zn}$ content for the $\mathrm{Zn}_{0.50^{-}}$and $\mathrm{Zn}_{1.00^{-}}$ series. For the three $\mathrm{Zn}$-doped samples heat treated at $1100^{\circ} \mathrm{C}$, about 2 wt. $\%$ of $\mathrm{ZnO}$ is inserted into HAp corresponding to the composition $\mathrm{Ca}_{10} \mathrm{Zn}_{0.25}\left(\mathrm{PO}_{4}\right)_{6}(\mathrm{OH})_{1.5} \mathrm{O}_{0.5}$; close to the refined composition of the Zn-HAp crystallographic structure previously described [16]. The formation of an interstitial solid solution is evidenced by refining the $\mathrm{Zn}$ occupancy in the $2 b$ Wyckoff site, and is also clearly evidenced by the anisotropic evolution of the HAp lattice parameters: $a$ lattice parameter is decreasing whereas $c$ lattice parameter is increasing when entering small $\mathrm{Zn}^{2+}$ cations. The $x=0.25$ limit value corresponds to $25 \%$ of the $\mathrm{Ca}_{10} \mathrm{Zn}\left(\mathrm{PO}_{4}\right)_{6} \mathrm{O}_{2}$ composition allowed by electroneutrality consideration only. When considering $\mathrm{Zn}$ atom located in HAp, $\beta$-TCP and $\mathrm{ZnO}$ for all temperature it clearly appears that from about $800^{\circ} \mathrm{C}$ all the nominal $\mathrm{Zn}$ content is detectable by XRPD (Figure 8). This is not the case between $500^{\circ} \mathrm{C}$ and $700^{\circ} \mathrm{C}$. A part of $\mathrm{Zn}$ is either contained in an amorphous compound and/or physisorbed at the HAp surface. At $600^{\circ} \mathrm{C}$ the divergence reaches its maximal value for the three series, but presence of $\alpha$-TCP (metastable at this temperature [43]) that can incorporate $\mathrm{Zn}$ should be considered (i.e. refined $\mathrm{Zn}$ content is underestimated at $600^{\circ} \mathrm{C}$ ). One can remark that the higher the $\mathrm{Zn}$ nominal content, the higher the divergence. The undetectable $\mathrm{Zn}$ content highly increases from the $\mathrm{Zn}_{0.25}$-series (for which total refined Zn content continuously agrees relatively well with the targeted value of $1.60 \mathrm{wt} . \%$ ) to the $\mathrm{Zn}_{1.00}$-series. The part of $\mathrm{Zn}$ atoms that is not located below $800^{\circ} \mathrm{C}$, followed by the $\mathrm{Zn}$ transfer from $\beta$-TCP to HAp between $800^{\circ} \mathrm{C}$ and $1000^{\circ} \mathrm{C}$, could explain the contradictions in 
the literature in term of $\mathrm{Zn}$ environments. The $\mathrm{Zn}$ environments in samples heat treated at $500^{\circ} \mathrm{C}$ (in amorphous compound, or probably physisorbed at the HAp surface), is clearly not the same that those from samples heat treated at $700-900^{\circ} \mathrm{C}$ (with the presence of $\mathrm{Zn}$ substituted $\beta$-TCP), and not the same as those from samples heat treated at $1000-1100^{\circ} \mathrm{C}$ (with formation of linear O-Zn-O entities in HAp structure).

\section{5- Conclusion}

Rietveld analyses performed on XRPD patterns from undoped and Zn-doped HAp samples heat treated between $500^{\circ} \mathrm{C}$ and $1100^{\circ} \mathrm{C}$ strengthen and explicit the mechanism of $\mathrm{Zn}$ insertion in the interstitial $2 b$ Wyckoff position of the HAp structure previously described and corresponding to the general $\mathrm{Ca}_{10} \mathrm{Zn}_{x}\left(\mathrm{PO}_{4}\right)_{6}(\mathrm{OH})_{2-2 x} \mathrm{O}_{2 x}$ composition [16]. For moderate heat treatment temperature, $\mathrm{Zn}$ stabilizes the $\beta$-TCP phase by substituting calcium in the low density column of the $\beta$-TCP structure (i.e. $\mathrm{Ca} 4$ and $\mathrm{Ca} 5$ sites). $\mathrm{Up}$ to $800^{\circ} \mathrm{C}$ weak quantity of $\mathrm{Zn}$ enters the interstitial hexagonal channel of the HAp phase; $\mathrm{Ca}_{10} \mathrm{Zn}_{x}\left(\mathrm{PO}_{4}\right)_{6}(\mathrm{OH})_{2-2 x} \mathrm{O}_{2 x}$ with a $x$ value around 0.07 only. At $800^{\circ} \mathrm{C}-900^{\circ} \mathrm{C}$ about 25 wt. $\%$ of $\beta$-TCP is observed (with about 2 wt. $\%$ of joint $\mathrm{CaO}$ phase due to the nominal $\mathrm{Ca} / \mathrm{P}$ ratio of 1.67$)$. The $\mathrm{Zn}$ quantity inserted at this stage in $\beta$-TCP leads to the composition $\mathrm{Ca}_{2.67} \mathrm{Zn}_{0.33}\left(\mathrm{PO}_{4}\right)_{2}$. Above $900^{\circ} \mathrm{C}$, $\mathrm{Zn}$ inserted in larger extent the hexagonal channel of HAp structure, and consequently destabilizes the $\beta$ TCP phase (by consuming the $\mathrm{CaO}$ phase formed at intermediate temperatures). The $\mathrm{Zn}$ doped HAp phase reaches a composition close to $\mathrm{Ca}_{10} \mathrm{Zn}_{0.25}\left(\mathrm{PO}_{4}\right)_{6}(\mathrm{OH})_{1.5} \mathrm{O}_{0.5}$, $\mathrm{Ca}_{10} \mathrm{Zn}_{x}\left(\mathrm{PO}_{4}\right)_{6}(\mathrm{OH})_{2-2 x} \mathrm{O}_{2 x}$ with $x=0.25$, which appears to be the maximal value of zinc insertion into HAp. The high temperature insertion of $\mathrm{Zn}$ into HAp stabilizes the $\beta$-TCP phase at moderate temperature and is certainly at the origin of the reported inhibiting effect of zinc on HAp crystallisation and the preference of $\mathrm{Zn}$ for $\beta$-TCP [17,41,42], which are not at all maintained at $1000^{\circ} \mathrm{C}$ and $1100^{\circ} \mathrm{C}$. The environment of $\mathrm{Zn}$ atoms (without considering the 
excess contained in zincite for the two $\mathrm{Zn}_{0.50^{-}}$and $\mathrm{Zn}_{1.00^{-}}$series) is temperature dependant because $\mathrm{Zn}$ moves from a non-definite position at $500^{\circ} \mathrm{C}$ (in an amorphous compound or physisorbed at HAp surface), to a partial substitution in the low-density column of the $\beta$-TCP structure at around $800^{\circ} \mathrm{C}$, and finally to the insertion in the hexagonal channel of the HAp structure (in the $2 b$ site, and forming linear O-Zn-O entities). Such a temperature dependent mechanism for $\mathrm{Zn}$ incorporation into HAp material should be considered by researchers when working on the biological effects of $\mathrm{Zn}$-containing calcium phosphate materials. In particular, material preparation method should be clearly indicated and careful characterization should be carried out.

\section{Acknowledgements}

This work was supported by ANR under project NANOSHAP (ANR-09-BLAN-0120-03). 
Table 1. Nominal and experimental (determined by ICP-AES with standard deviations indicated) compositions for the four synthesized series.

\begin{tabular}{|l|lllll|lllll|}
\hline & \multicolumn{4}{|c|}{ Nominal targeted composition } & \multicolumn{5}{c|}{ Experimental composition } \\
& $\mathrm{CaO}(\mathrm{wt} \%)$ & $\mathrm{P}_{2} \mathrm{O}_{5}(\mathrm{wt} \%)$ & $\mathrm{Ca} / \mathrm{P}$ & $\mathrm{ZnO}(\mathrm{wt} \%)$ & $\mathrm{x}^{a}$ & $\mathrm{CaO}(\mathrm{wt} \%)$ & $\mathrm{P}_{2} \mathrm{O}_{5}(\mathrm{wt} \%)$ & $\mathrm{Ca} / \mathrm{P}$ & $\mathrm{ZnO}(\mathrm{wt} \%)$ & $\mathrm{x}^{a}$ \\
$\mathrm{Zn}_{0.00^{-}}$-series & 56.84 & 43.16 & 1.67 & - & 0.00 & $57 \pm 1$ & $43.1 \pm 0.9$ & $1.67 \pm 0.04$ & - \\
$\mathrm{Zn}_{0.25}$ - series & 55.69 & 42.29 & 1.67 & 2.00 & 0.25 & $56 \pm 1$ & $42.7 \pm 0.9$ & $1.67 \pm 0.04$ & $2.0 \pm 0.1$ & $0.25 \pm 0.01$ \\
$\mathrm{Zn}_{0.50^{-}}$series & 54.59 & 41.45 & 1.67 & 3.93 & 0.50 & $55 \pm 1$ & $41.2 \pm 0.8$ & $1.69 \pm 0.04$ & $4.0 \pm 0.2$ & $0.51 \pm 0.03$ \\
$\mathrm{Zn}_{1.00^{-}}$series & 52.51 & 39.87 & 1.67 & 7.62 & 1.00 & $53 \pm 1$ & $40.4 \pm 0.8$ & $1.68 \pm 0.04$ & $7.6 \pm 0.4$ & $0.98 \pm 0.05$ \\
\hline
\end{tabular}

${ }^{a} \mathrm{x}$ value from the global composition $\mathrm{Ca}_{10} \mathrm{Zn}_{x}\left(\mathrm{PO}_{4}\right)_{6} \mathrm{O}_{2 x}(\mathrm{OH})_{2-2 x}$. 
Table 2. Results of the quantitative analyses (wt. \%) extracted from Rietveld refinements.

Standard deviations, corresponding to $\sigma$ values given by FullProf output files, are indicated in parentheses.

\begin{tabular}{|c|c|c|c|c|c|c|}
\hline \multirow{2}{*}{ series } & \multirow{2}{*}{ samples } & \multicolumn{5}{|c|}{ Mineralogical composition (wt. \%) } \\
\hline & & HAp & $\beta$-ТCP & $\alpha-\mathrm{TCP}$ & $\mathrm{ZnO}$ & $\mathrm{CaO}$ \\
\hline \multirow[t]{7}{*}{$\mathrm{Zn}_{0.00}$-series } & $\mathrm{Zn}_{0.00^{-}} 500$ & $99.4(3)$ & - & - & - & $0.64(2)$ \\
\hline & $\mathrm{Zn}_{0.00}-600$ & $91.5(3)$ & $3.0(1)$ & $4.7(1)$ & - & $0.78(2)$ \\
\hline & $\mathrm{Zn}_{0.00^{-}}-700$ & $86.8(3)$ & $7.9(1)$ & $4.2(1)$ & - & $1.10(2)$ \\
\hline & $\mathrm{Zn}_{0.00}-800$ & $81.7(3)$ & $14.3(2)$ & $2.8(1)$ & - & $1.18(3)$ \\
\hline & $\mathrm{Zn}_{0.00}-900$ & $80.3(3)$ & $18.8(2)$ & - & - & $0.89(2)$ \\
\hline & $\mathrm{Zn}_{0.00}-1000$ & $89.0(3)$ & $10.6(1)$ & - & - & $0.38(2)$ \\
\hline & $\mathrm{Zn}_{0.00}-1100$ & $97.5(4)$ & $2.51(8)$ & - & - & - \\
\hline \multirow{7}{*}{$\mathrm{Zn}_{0.25^{-}}$series } & $\mathrm{Zn}_{0.25}-500$ & $98.3(3)$ & - & - & $1.18(2)$ & $0.51(2)$ \\
\hline & $\mathrm{Zn}_{0.25}-600$ & $88.5(4)$ & $6.4(2)$ & $3.8(1)$ & $0.71(2)$ & $0.64(2)$ \\
\hline & $\mathrm{Zn}_{0.25^{-}}-700$ & $82.1(4)$ & $16.3(3)$ & - & $0.51(2)$ & $1.09(2)$ \\
\hline & $\mathrm{Zn}_{0.25}-800$ & $78.0(3)$ & $20.0(2)$ & - & $0.56(2)$ & $1.43(3)$ \\
\hline & $\mathrm{Zn}_{0.25}-900$ & $76.7(3)$ & $21.3(2)$ & - & $0.66(2)$ & $1.29(2)$ \\
\hline & $\mathrm{Zn}_{0.25}-1000$ & $82.3(3)$ & $11.7(2)$ & - & $0.43(2)$ & $0.60(2)$ \\
\hline & $\mathrm{Zn}_{0.25}-1100$ & $96.5(3)$ & $3.46(9)$ & - & $0.16(2)$ & - \\
\hline \multirow[t]{7}{*}{$\mathrm{Zn}_{0.50^{-}}$series } & $\mathrm{Zn}_{0.50^{-}}-500$ & $97.3(3)$ & - & - & $2.17(5)$ & $0.56(2)$ \\
\hline & $\mathrm{Zn}_{0.50^{-}}-600$ & $87.3(4)$ & $6.8(3)$ & $3.6(1)$ & $1.51(2)$ & $0.75(2)$ \\
\hline & $\mathrm{Zn}_{0.50^{-}}-700$ & $82.2(4)$ & $15.3(2)$ & - & $1.33(2)$ & $1.26(2)$ \\
\hline & $\mathrm{Zn}_{0.50}-800$ & $74.1(3)$ & $22.7(2)$ & - & $1.53(3)$ & $1.67(2)$ \\
\hline & $\mathrm{Zn}_{0.50^{-}}-900$ & $70.1(2)$ & $26.4(2)$ & - & $1.95(2)$ & $1.50(2)$ \\
\hline & $\mathrm{Zn}_{0.50^{-}}-1000$ & $79.7(3)$ & $17.5(2)$ & - & $2.33(2)$ & $0.45(2)$ \\
\hline & $\mathrm{Zn}_{0.50}-1100$ & $95.4(4)$ & $3.1(1)$ & - & $1.52(2)$ & - \\
\hline \multirow[t]{7}{*}{$\mathrm{Zn}_{1.00^{-}}$series } & $\mathrm{Zn}_{1.00}-500$ & $95.2(4)$ & - & - & $4.48(7)$ & $0.37(2)$ \\
\hline & $\mathrm{Zn}_{1.00}-600$ & $81.5(5)$ & $10.6(4)$ & $3.34(2)$ & $3.42(3)$ & $1.12(2)$ \\
\hline & $\mathrm{Zn}_{1.00}-700$ & $74.5(4)$ & $19.5(2)$ & - & $3.66(4)$ & $2.37(3)$ \\
\hline & $\mathrm{Zn}_{1.00}-800$ & $68.4(3)$ & $24.7(2)$ & - & $4.35(3)$ & $2.50(3)$ \\
\hline & $\mathrm{Zn}_{1.00}-900$ & $64.6(2)$ & $27.9(2)$ & - & $5.40(3)$ & $2.12(2)$ \\
\hline & $\mathrm{Zn}_{1.00}-1000$ & $75.4(3)$ & $17.6(2)$ & - & $5.91(3)$ & $1.00(2)$ \\
\hline & $\mathrm{Zn}_{1.00}-1100$ & $93.5(4)$ & $1.27(8)$ & - & $5.24(4)$ & - \\
\hline
\end{tabular}


Table 3. HAp structural and microstructural parameters extracted from Rietveld refinements.

Standard deviations, corresponding to $\sigma$ values given by FullProf output files, are indicated in parentheses.

\section{HAp}

series samples

$$
a(\AA) \quad c(\AA) \quad \mathrm{V}\left(\AA^{3}\right) \quad \mathrm{Zn}(\%)^{*}
$$

Crystal size

$[h h 0](\AA) \quad[00 l](\AA)$

\begin{tabular}{cccccccc}
\hline \multirow{2}{*}{$\mathrm{Zn}_{0.00}$} & $\mathrm{Zn}_{0.00}-500$ & $9.4263(1)$ & $6.8815(1)$ & $529.53(1)$ & - & 240 & 310 \\
& $\mathrm{Zn}_{0.00}-600$ & $9.4190(1)$ & $6.88315(8)$ & $528.85(1)$ & - & 260 & 320 \\
& $\mathrm{Zn}_{0.00}-700$ & $9.41782(7)$ & $6.88401(6)$ & $528.778(7)$ & - & 310 & 370 \\
& $\mathrm{Zn}_{0.00}-800$ & $9.4182(1)$ & $6.8825(1)$ & $528.70(1)$ & - & 450 & 500 \\
& $\mathrm{Zn}_{0.00}-900$ & $9.42052(3)$ & $6.88127(3)$ & $528.870(3)$ & - & 620 & 670 \\
& $\mathrm{Zn}_{0.00}-1000$ & $9.42048(2)$ & $6.88158(2)$ & $528.889(3)$ & - & 820 & 850 \\
& $\mathrm{Zn}_{0.00}-1100$ & $9.42016(2)$ & $6.88203(2)$ & $528.888(2)$ & - & 910 & 930 \\
\hline $\mathrm{Zn}_{0.25}$ & $\mathrm{Zn}_{0.25}-500$ & $9.4235(1)$ & $6.8845(1)$ & $529.46(1)$ & $3.6(3)$ & 260 & 320 \\
& $\mathrm{Zn}_{0.25}-600$ & $9.4166(1)$ & $6.8853(1)$ & $528.74(1)$ & $3.0(3)$ & 290 & 350 \\
& $\mathrm{Zn}_{0.25}-700$ & $9.41629(8)$ & $6.88425(7)$ & $528.624(8)$ & $3.0(3)$ & 320 & 370 \\
& $\mathrm{Zn}_{0.25}-800$ & $9.41864(6)$ & $6.88276(5)$ & $528.773(6)$ & $3.0(3)$ & 470 & 490 \\
& $\mathrm{Zn}_{0.25}-900$ & $9.41854(4)$ & $6.88548(4)$ & $528.971(5)$ & $5.4(3)$ & 630 & 650 \\
& $\mathrm{Zn}_{0.25}-1000$ & $9.41717(3)$ & $6.89363(2)$ & $529.444(3)$ & $9.6(3)$ & 770 & 780 \\
& $\mathrm{Zn}_{0.25}-1100$ & $9.41272(2)$ & $6.90081(2)$ & $529.494(2)$ & $10.8(3)$ & 860 & 870 \\
\hline $\mathrm{Zn}_{0.50}$ & $\mathrm{Zn}_{0.50}-500$ & $9.4228(1)$ & $6.8849(1)$ & $529.41(1)$ & $3.6(3)$ & 270 & 340 \\
& $\mathrm{Zn}_{0.50}-600$ & $9.4173(1)$ & $6.8857(1)$ & $528.85(1)$ & $4.2(3)$ & 300 & 370 \\
& $\mathrm{Zn}_{0.50}-700$ & $9.41654(9)$ & $6.88526(8)$ & $528.730(9)$ & $3.6(3)$ & 330 & 390 \\
& $\mathrm{Zn}_{0.50}-800$ & $9.41815(7)$ & $6.88370(3)$ & $528.791(8)$ & $3.6(3)$ & 480 & 510 \\
& $\mathrm{Zn}_{0.50}-900$ & $9.41909(5)$ & $6.88605(4)$ & $529.077(5)$ & $5.4(3)$ & 600 & 620 \\
& $\mathrm{Zn}_{0.50}-1000$ & $9.41665(3)$ & $6.89355(3)$ & $529.378(3)$ & $9.0(3)$ & 760 & 770 \\
& $\mathrm{Zn}_{0.50}-1100$ & $9.41153(4)$ & $6.90100(3)$ & $529.375(4)$ & $11.2(3)$ & 870 & 870 \\
\hline $\mathrm{Zn}_{1.00}$ & $\mathrm{Zn}_{1.00}-500$ & $9.4242(2)$ & $6.8863(1)$ & $529.68(2)$ & $4.2(3)$ & 270 & 340 \\
& $\mathrm{Zn}_{1.00}-600$ & $9.4170(1)$ & $6.88611(9)$ & $528.85(1)$ & $4.8(3)$ & 290 & 360 \\
& $\mathrm{Zn}_{1.00}-700$ & $9.41677(8)$ & $6.88440(7)$ & $528.535(9)$ & $3.0(3)$ & 400 & 470 \\
& $\mathrm{Zn}_{1.00}-800$ & $9.41833(7)$ & $6.88249(6)$ & $528.718(8)$ & $3.6(3)$ & 520 & 550 \\
& $\mathrm{Zn}_{1.00}-900$ & $9.41882(5)$ & $6.88520(4)$ & $528.981(5)$ & $4.2(3)$ & 620 & 650 \\
& $\mathrm{Zn}_{1.00}-1000$ & $9.41762(3)$ & $6.89376(3)$ & $529.504(3)$ & $8.4(3)$ & 760 & 770 \\
& $\mathrm{Zn}_{1.00}-1100$ & $9.41382(4)$ & $6.90157(4)$ & $529.676(4)$ & $12.6(3)$ & 880 & 880 \\
\hline
\end{tabular}

Occupancy of $\mathrm{Zn}$ in the $2 b$ Wyckoff site. 
Table 4. $\beta$-TCP structural and microstructural parameters extracted from Rietveld refinements. Standard deviations, corresponding to $\sigma$ values given by FullProf output files, are indicated in parentheses.

\begin{tabular}{|c|c|c|c|c|c|c|c|}
\hline \multirow{3}{*}{ series } & \multirow{3}{*}{ samples } & \multicolumn{6}{|c|}{$\beta$-ТCP } \\
\hline & & \multirow{2}{*}{$a(\AA)$} & \multirow{2}{*}{$c(\AA)$} & \multirow{2}{*}{$V\left(\AA^{3}\right)$} & \multicolumn{2}{|c|}{$\mathrm{Zn}^{*}$} & \multirow{2}{*}{$\begin{array}{l}\text { Crystal } \\
\operatorname{size}(\AA)\end{array}$} \\
\hline & & & & & $\mathrm{Ca} 4(\%)$ & $\mathrm{Ca} 5(\%)$ & \\
\hline \multirow{7}{*}{$\mathrm{Zn}_{0.00}$} & $\mathrm{Zn}_{0.00^{-}} 500$ & - & - & - & - & - & - \\
\hline & $\mathrm{Zn}_{0.00}-600$ & $10.444(1)$ & $37.382(5)$ & $3531.2(7)$ & - & - & 380 \\
\hline & $\mathrm{Zn}_{0.00^{-}}-700$ & $10.4394(4)$ & $37.383(2)$ & $3528.2(3)$ & - & - & 420 \\
\hline & $\mathrm{Zn}_{0.00^{-}} 800$ & $10.4367(5)$ & $37.389(2)$ & $3527.0(3)$ & - & - & 540 \\
\hline & $\mathrm{Zn}_{0.00^{-}}-900$ & $10.4367(1)$ & $37.3907(5)$ & $3527.10(7)$ & - & - & 680 \\
\hline & $\mathrm{Zn}_{0.00}-1000$ & $10.4349(2)$ & 37.3889 (8) & 3525.8 (1) & - & - & 790 \\
\hline & $\mathrm{Zn}_{0.00}-1100$ & $10.4309(5)$ & $37.385(1)$ & $3522.6(2)$ & - & - & 960 \\
\hline \multirow[t]{7}{*}{$\mathrm{Zn}_{0.25}$} & $\mathrm{Zn}_{0.25}-500$ & - & - & - & - & - & - \\
\hline & $\mathrm{Zn}_{0.25}-600$ & $10.380(1)$ & $37.255(5)$ & $3476.2(7)$ & $50(-)$ & $0(-)$ & 210 \\
\hline & $\mathrm{Zn}_{0.25}-700$ & $10.3573(5)$ & $37.268(2)$ & $3462.3(3)$ & $31(6)$ & $58(5)$ & 230 \\
\hline & $\mathrm{Zn}_{0.25}-800$ & $10.3717(2)$ & $37.2670(8)$ & $3471.8(1)$ & $8(1)$ & $74(3)$ & 320 \\
\hline & $\mathrm{Zn}_{0.25}-900$ & $10.3974(2)$ & 37.3209 (7) & $3494.1(1)$ & $8(1)$ & $50(3)$ & 610 \\
\hline & $\mathrm{Zn}_{0.25}-1000$ & $10.4112(2)$ & $37.3630(9)$ & $3507.3(1)$ & $50(-)$ & $10(5)$ & 670 \\
\hline & $\mathrm{Zn}_{0.25}-1100$ & $10.4173(8)$ & $37.375(3)$ & $3512.6(5)$ & - & - & 820 \\
\hline \multirow{7}{*}{$\mathrm{Zn}_{0.50}$} & $\mathrm{Zn}_{0.50^{-}}-500$ & - & - & - & - & - & - \\
\hline & $\mathrm{Zn}_{0.50}-600$ & $10.355(2)$ & $37.213(8)$ & $3456(1)$ & $50(-)$ & $0(-)$ & 140 \\
\hline & $\mathrm{Zn}_{0.50^{-}}-700$ & $10.3431(5)$ & $37.230(2)$ & $3449.3(3)$ & $39(7)$ & $36(6)$ & 230 \\
\hline & $\mathrm{Zn}_{0.50^{-}} 800$ & $10.3493(2)$ & $37.2582(8)$ & $3456.0(1)$ & $4(1)$ & $94(3)$ & 350 \\
\hline & $\mathrm{Zn}_{0.50^{-}}-900$ & $10.3868(2)$ & 37.2955 (7) & $3484.6(1)$ & $8(1)$ & $62(2)$ & 700 \\
\hline & $\mathrm{Zn}_{0.50}-1000$ & $10.4148(1)$ & $37.3680(6)$ & $3510.23(9)$ & $50(-)$ & $20(3)$ & 720 \\
\hline & $\mathrm{Zn}_{0.50}-1100$ & $10.4181(9)$ & $37.360(4)$ & $3511.7(5)$ & - & - & 840 \\
\hline $\mathrm{Zn}_{1.00}$ & $\mathrm{Zn}_{1.00}-500$ & - & - & - & - & - & - \\
\hline
\end{tabular}




\begin{tabular}{ccccccc}
\hline $\mathrm{Zn}_{1.00}-600$ & $10.330(2)$ & $37.21(1)$ & $3439(1)$ & $50(-)$ & $13(9)$ & 180 \\
$\mathrm{Zn}_{1.00}-700$ & $10.3332(2)$ & $37.224(1)$ & $3442.1(1)$ & $19(5)$ & $100(-)$ & 380 \\
$\mathrm{Zn}_{1.00}-800$ & $10.3441(2)$ & $37.2296(8)$ & $3449.9(1)$ & $4(1)$ & $100(-)$ & 490 \\
$\mathrm{Zn}_{1.00}-900$ & $10.3847(2)$ & $37.2957(6)$ & $3483.19(9)$ & $7(1)$ & $73(4)$ & 690 \\
$\mathrm{Zn}_{1.00}-1000$ & $10.4141(2)$ & $37.3704(6)$ & $3509.99(9)$ & $40(4)$ & $24(3)$ & 690 \\
$\mathrm{Zn}_{1.00}-1100$ & $10.418(1)$ & $37.355(5)$ & $3511.1(7)$ & - & - & 780 \\
\hline
\end{tabular}

* Occupancies of $\mathrm{Zn}$ in the $\mathrm{Ca} 4$ and $\mathrm{Ca} 5$ calcium sites from $\beta$-TCP structure. ${ }^{34}$ 
Table 5. Raman spectra decomposition of the $\mathrm{Zn}_{0.00^{-}}$and $\mathrm{Zn}_{0.25}$-series. Raman shift and full width at half maximum (FWHM, in parentheses) for symetric stretching mode of phosphate tetrahedron and hydroxyl stretching.

\begin{tabular}{|c|c|c|c|c|}
\hline \multirow[b]{2}{*}{ Temperature } & \multicolumn{2}{|c|}{$\mathrm{Zn}_{0.00}$-series } & \multicolumn{2}{|c|}{$\mathrm{Zn}_{0.25}$-series } \\
\hline & $\begin{array}{c}\mathrm{U}_{1}\left[\mathrm{PO}_{4}\right] \\
\left(\mathrm{cm}^{-1}\right)\end{array}$ & $\begin{array}{c}{[\mathrm{OH}] \text { stretching }} \\
\left(\mathrm{cm}^{-1}\right)\end{array}$ & $\begin{array}{c}\mathrm{U}_{1}\left[\mathrm{PO}_{4}\right] \\
\left(\mathrm{cm}^{-1}\right)\end{array}$ & $\begin{array}{c}{[\mathrm{OH}] \text { stretching }} \\
\left(\mathrm{cm}^{-1}\right)\end{array}$ \\
\hline $500^{\circ} \mathrm{C}$ & $963(6.4)$ & $3572(10.1)$ & $963(7.7)$ & $3572(12.3)$ \\
\hline $600^{\circ} \mathrm{C}$ & $963(6.3)$ & $3572(8.7)$ & $963(6.2)$ & $3572(10.3)$ \\
\hline $700^{\circ} \mathrm{C}$ & $964(6.1)$ & $3572(8.4)$ & $963(5.8)$ & $3572(7.5)$ \\
\hline $800^{\circ} \mathrm{C}$ & $963(5.1)$ & $3572(5.4)$ & $963(4.9)$ & $3572(5.0)$ \\
\hline $900^{\circ} \mathrm{C}$ & $963(4.8)$ & $3572(4.2)$ & 963 (5.6) & $\begin{array}{c}3410(26.6) \\
3572(7.1)\end{array}$ \\
\hline $1000^{\circ} \mathrm{C}$ & $963(3.7)$ & 3572 (2.9) & $\begin{array}{l}959(6.1)^{*} \\
963(6.1)^{*} \\
970(6.1)\end{array}$ & $\begin{array}{c}3411(25.4) \\
3572(8.4)\end{array}$ \\
\hline $1100^{\circ} \mathrm{C}$ & $963(3.7)$ & $3572(3.0)$ & $\begin{array}{l}959(6.3)^{*} \\
964(6.3)^{*} \\
970(6.3)^{*}\end{array}$ & $\begin{array}{l}3412(25.3) \\
3572(8.8) \\
3584(1.2)\end{array}$ \\
\hline
\end{tabular}

${ }^{*}$ FWHM of the three $v_{1}$ components were constraint to be equal during the deconvolution procedure. 
Figure 1. PXRD patterns for the $\mathrm{Zn}_{0.25}$-series $(\lambda=1.54184 \AA$ ). Major phase is HAp for all patterns, minor phases are $\mathrm{ZnO}, \alpha-\mathrm{TCP}, \mathrm{CaO}$ and $\beta$-TCP (for which main diffraction peaks are respectively marked by $+, *, "$, and ${ }^{\circ}$ ).

Figure 2. Quantitative phases analyses extracted from Rietveld refinement (a: HAp and $\beta$ TCP phases, b: $\mathrm{ZnO}$, and $\mathrm{c}$ : $\mathrm{CaO}$ ) performed for the undoped $\mathrm{Zn}_{0.00}$-series (open squares symbols, dashed lines), and the $\mathrm{Zn}$-doped $\mathrm{Zn}_{0.25}$-series (full circles), $\mathrm{Zn}_{0.50}$-series (full diamonds), $\mathrm{Zn}_{1.00}$-series (full stars).

Figure 3. Thermal evolutions of the HAp lattice parameters (a: parameter $a$, b: parameter $c$ ), the HAp unit cell volume (c), and the Zn occupancy factor in the $2 b$ Wyckoff site (d) for the undoped $\mathrm{Zn}_{0.00}$-series (open squares symbols, dashed lines), and the $\mathrm{Zn}$-doped $\mathrm{Zn}_{0.25}$-series (full circles), $\mathrm{Zn}_{0.50}$-series (full diamonds), $\mathrm{Zn}_{1.00}$-series (full stars). Error bars correspond to $3 \sigma$ (within symbols for lattice parameters and unit cell volumes).

Figure 4. Thermal evolutions of the $\beta$-TCP lattice parameters (a: parameter $a$, b: parameter $c$ ), and the $\beta$-TCP unit cell volume (c) for the undoped $\mathrm{Zn}_{0.00}$-series (open squares symbols, dashed line), and the $\mathrm{Zn}$-doped $\mathrm{Zn}_{0.25}$-series (full circles), $\mathrm{Zn}_{0.50^{-}}$-series (full diamonds), $\mathrm{Zn}_{1.00^{-}}$ series (full stars). Ca substitution percent is represented (d) in site Ca4 (full symbols) and in site Ca5 (open symbols, dotted lines). Error bars correspond to $3 \sigma$. 
Figure 5. HAp crystal size anisotropy $([00 l] /[h h 0]$ direction sizes ratio) for the undoped $\mathrm{Zn}_{0.00}$-series (open squares symbols, dashed line), and the $\mathrm{Zn}$-doped $\mathrm{Zn}_{0.25}$-series (full circles), $\mathrm{Zn}_{0.50}$-series (full diamonds), $\mathrm{Zn}_{1.00}$-series (full stars).

Figure 6. Details of the Raman spectra showing the thermal evolution of the $v_{1}$ mode of vibration of $\left[\mathrm{PO}_{4}\right]$ for the undoped $\mathrm{Zn}_{0.00}$-series (left) and the $\mathrm{Zn}$-doped $\mathrm{Zn}_{0.25}$-series (right).

Figure 7. Raman spectra showing the $[\mathrm{OH}]$ vibrations for the undoped $\mathrm{Zn}_{0.00}$-series (left) and the $\mathrm{Zn}$-doped $\mathrm{Zn}_{0.25}$-series (right).

Figure 8. Total refined $\mathrm{Zn}$ content (from the three $\mathrm{Zn}$-doped HAp, Zn-doped $\beta$-TCP and ZnO phases) for the $\mathrm{Zn}$-doped $\mathrm{Zn}_{0.25}$-series (full circles), $\mathrm{Zn}_{0.50}$-series (full diamonds), $\mathrm{Zn}_{1.00}$-series (full stars). Dotted horizontal lines correspond to nominal targetted values: respectively 1.6, 3.2 and 6.1 wt. $\%$. 


\section{References}

[1] Elliot J.C., in Structure and chemistry of the apatites and other calcium orthophosphates, Amsterdam: Elsevier; 1994.

[2] Cazalbou S., Combes C., Eichert D., Rey C., Adaptative physico-chemistry of bio-related calcium phosphates, J. Mater. Chem 2004, 14, 2148-2153.

[3] Bazin D., Carpentier X., Traxer O., Thiaudiere D., Somogyi A. Reguer et al., Very first tests on SOLEIL regarding the $\mathrm{Zn}$ environment in pathological calcifications made of apatite determined by X-ray absorption spectroscopy, J. Synchrotron Radiat. 2008, 15, 506-509.

[4] Murray E.J., Messer H.H., Turnover of Bone Zinc during Normal and Accelerated Bone Loss in Rats, J. Nutr. 1981, 111, 1641-1647.

[5] Bazin D., Chevallier P., Matzen G., Jungers P., Daudon M., Heavy elements in urinary stones, Urol. Res. 2007, 35, 179-184.

[6] Ito A., Otsuka M., Kawamura H., Ikeuchi M., Ohgushi H., Sogo Y. et al., Zinc-containing tricalcium phosphate and related materials for promoting bone formation, Curr. Appl. Phys. $2005,5,402-406$.

[7] Yamaguchi M., Oishi H., Suketa Y., Stimulatory effect of zinc on bone-formation in tissue-culture, Biochem. Pharmacol. 1987, 36(22), 4007-4012.

[8] Yamaguchi M., Yamaguchi R., Action of zinc on bone metabolism in rats - increases in alkaline-phosphatase activity and DNA content, Biochem. Pharmacol. 1986, 35(5), 773-777.

[9] Wang X., Ito A., Sogo Y., Li X., Oyane A., Zinc-containing apatite layers on external fixation rods promoting cell activity, Acta Biomater. 2010, 6, 962-968.

[10] Ito A., Kawamura H., Otsuka M., Ikeuchi M., Ohgushi H., Ishikawa K., Zinc-releasing calcium phosphate for stimulating bone formation, Mater. Sci. Eng. 2002, C22, 21-25. 
[11] Ito, A.; Ojima, K.; Naito, H.; Ichinose, N.; Tateishi, T., Preparation, solubility, and cytocompatibility of zinc-releasing calcium phosphate ceramics, J. Biomed. Mater. Res. 2000, $50,178-183$.

[12] Jallot E., Nedelec J.-M., Grimault A.S., Chassot E., Grandjean-Laqueriere A., Laquerriere P. et al., STEM and EDXS characterisation of physico-chemical reactions at the periphery of sol-gel derived Zn-substituted hydroxyapatites during interactions with biological fluids, Colloids Surf. B 2005, 42, 205-210.

[13] Velard F., Laurent-Maquin D., Braux J., Guillaume C., Bouthors S., Jallot E. et al., The effect of zinc on hydroxyapatite-mediated activation of human polymorphonuclear neutrophils and bone implant-associated acute inflammation, Biomaterials 2010, 31, 20012009.

[14] Grandjean-Laquerriere A., Laquerriere P., Jallot E., Nedelec J.-M., Guenounou M., Laurent-Maquin D. et al., Influence of the zinc concentration of sol-gel derived zinc substituted hydroxyapatite on cytokine production by human monocytes in vitro, Biomaterials 2006, 27, 3195-3200.

[15] Li J.D., Li Y.B., Zuo Y., Lv G.Y., Yang W.H., Tian Zh.Y., Antibacterial Effect and Security Evaluation on Nano-Hydroxyapatite Bearing $\mathrm{Cu}^{2+}$ and $\mathrm{Zn}^{2+}$, Mater. Sci. Forum 2006, 510-511, 890-893.

[16] Gomes S., Nedelec, J.-M., Jallot E., Sheptyakov D., Renaudin G., Unexpected Mechanism of $\mathrm{Zn}^{2+}$ Insertion in Calcium Phosphate Bioceramics, Chem. Mat. 2011, 23, 30723085 .

[17] Miyaji F., Kono Y., Suyama Y., Formation and structure of zinc-substituted calcium hydroxyapatite, Mater. Res. Bull. 2005, 40(2), 209-220.

[18] Patel P.N., Magnesium calcium hydroxylapatite solid-solutions - preparation, IR and lattice-constant measurements, J. Inorg. Nucl. Chem. 1980, 42(8), 1129-1132. 
[19] Bigi A., Foresti E., Gandolfi M., Gazzano M., Roveri N., Inhibiting effect of zinc on hydroxylapatite crystallization, J. Inorg. Biochem. 1995, 58(1), 49-58.

[20] Suzuki S., Fuzita T., Maruyama T., Takahashi M. and Hikichi Y., Cation-exchange characterics of sintered hydroxyapatite in the strongly acidic region, J. Amer. Ceram. Soc. 1993, 76(6), 1638-1640.

[21] Tang Y., Chappell H.F., Dove M.T., Reeder R.J., Lee Y.J., Zinc incorporation into hydroxylapatite, Biomaterials 2009, 30(15), 2864-2872.

[22] Barrea R.A., Pérez C.A., Ramos A.Y., Zinc incorporation in human dental calculus, $J$. Synchroton Rad. 2001, 8, 990-992.

[23] Takatsuka T., Hirano J., Matsumoto H., Honma T., X-Ray absorption fine structure analysis of the local environment of zinc in dentine treated with zinc compounds, Eur. J. Oral Sci. 2005, 113, 80-183.

[24] Matsunaga K., Murata H., Mizoguchi T., Nakahira A., Mechanism of incorporation of zinc into hydroxyapatite, Acta Biomater. 2010, 6(6), 2289-2293.

[25] Bazin D., Carpentier X., Brocheriou I., Dorfmuller P., Aubert S., Chappard C., Revisiting the localisation of $\mathrm{Zn}^{2+}$ cations sorbed on pathological apatite calcifications made through $\mathrm{X}$ ray absorption spectroscopy, Biochimie 2009, 91(10), 1294-1300.

[26] Terra J., Jiang M., Ellis D.E., Characterization of electronic structure and bonding in hydroxyapatite: Zn substitution for Ca, Philos. Mag. A 2002, 82(11), 2357 - 2377.

[27] Ma X., Ellis D.E., Initial stages of hydration and Zn substitution/occupation on hydroxyapatite (0001) surfaces, Biomaterials 2008, 29(3), 257-265.

[28] Matsunaga, K., First-principles study of substitutional magnesium and zinc in hydroxyapatite and octacalcium phosphate, J. Chem. Phys. 2008, 128(24), 245101-245110.

[29] Rodriguez-Carvajal J., PROGRAM FullProf.2k - version 3.20; Laboratoire Léon Brillouin (CEA-CNRS): Saclay, France, 2005; FullProf.2k manual available on http://www- 
llb.cea.fr/fullweb/fp2k/fp2k_divers.htm. See also Rodriguez-Carvajal, J.; Roisnel, T. EPDIC8; May 23-26, 2002; Trans. Tech. Publication: Uppsala, Sweden; Mater. Sci. Forum 2004, $123,443$.

[30] McCusker L.B., Von Dreele R.B., Cox D.E., Louër D., Scardi P., Rietveld refinement guidelines, J. Appl. Cryst. 1999, 32, 36-50.

[31] Hill R.J., - Rietveld refinement round-robin .1. analysis of standard x-ray and neutron data for $\mathrm{PbSO}_{4}$, J. Appl. Cryst. 1992, 25, 589-610.

[32] Scarlett N.V.Y., Madsen I.C., Cranswick L.M.D., Lwin T., Groleau E., Stephenson G. et al., Outcomes of the International Union of Crystallography Commission on Powder Diffraction Round Robin on Quantitative Phase Analysis: samples 2, 3, 4, synthetic bauxite, natural granodiorite and pharmaceuticals, J. Appl. Cryst. 2002, 35, 383-400.

[33] Rodriguez-Lorenzo L.M., Hart J.N., Gross A., Structural and chemical analysis of wellcrystallized hydroxyfluorapatites, J. Phys. Chem. B 2003, 107(33), 8316-8320.

[34] Yashima M., Sakai A., Kamiyama T., Hoshikawa A., Crystal structure analysis of betatricalcium phosphate $\mathrm{Ca}_{3}\left(\mathrm{PO}_{4}\right)_{2}$ by neutron powder diffraction, J. Sol. State Chem. 2003, $175(2), 272-277$.

[35] Abrahams S.C., Bernstein J.L., Remeasurement of structure of hexagonal ZnO, Acta Cryst. B 1969, B25, 1233-1236.

[36] Ganguly R., Siruguri V., Gopalakrishnan I.K., Yakhmi J.V., Stability of the layered $\mathrm{Sr}_{3} \mathrm{Ti}_{2} \mathrm{O}_{7}$ structure in $\mathrm{La}_{-1.2}\left(\mathrm{Sr}_{1-\mathrm{x}} \mathrm{Ca}_{\mathrm{x}}\right)\left({ }_{1.8}\right) \mathrm{Mn}_{2} \mathrm{O}_{7}$, J. Phys.: Condens. Matter 2000, 12, $1683-$ 1689.

[37] Mathew M., Schroeder L.W., Dickens B., Brown W.E., Crystal-structure of alpha$\mathrm{Ca}_{3}\left(\mathrm{PO}_{4}\right)_{2}$, Acta Cryst. B 1977, 33, 1325-1333. 
[38] Renaudin G., Jallot E., Nedelec J.-M., Effect of Strontium Substitution on the Composition and Microstructure of Sol-Gel Derived Calcium Phosphates, J. Sol-Gel Science and Technology 2009, 1(3), 287-294.

[39] Palard M., Champion E., Foucaud S., Synthesis of silicated hydroxyapatite $\mathrm{Ca}_{10}\left(\mathrm{PO}_{4}\right)_{(6-}$ ${ }_{\mathrm{x})}\left(\mathrm{SiO}_{4}\right)_{(\mathrm{x})}(\mathrm{OH})_{(2-\mathrm{x})}$, J. Sol. State Chem. 2008, 181, 1950-1960.

[40] Gomes S., Renaudin G., Jallot E., Nedelec J.-M., Structural Characterization and Biological Fluid Interaction of Sol-Gel-Derived Mg-Substituted Biphasic Calcium Phosphate Ceramics, Appl. Mater. Interfaces 2009, 1(2), 505-513.

[41] Ren F., Xin R., Ge X., Leng Y., Characterization and structural analysis of zincsubstituted hydroxyapatites, Acta Biomater. 2009, 5(8), 3141-3149.

[42] Li M.O., Xiao X., Liu R., Chen C., Huang L., Structural characterization of zincsubstituted hydroxyapatite prepared by hydrothermal method, J. Mater. Sci.: Mater. Med. 2008, 19(2), 797-803.

[43] Carrodeguas R.G., De Aza S., $\alpha$-Tricalcium phosphate: Synthesis, properties and biomedical applications, Acta Biomater. 2011, doi:10.1016/j.actbio.2011.06.019. 